\title{
Biochemical and molecular characterization of cellulase producing bacterial isolates from cattle dung samples
}

\author{
Preeti Vyas and Ashwani Kumar* \\ Metagenomics and Secretomics Research Laboratory, Department of Botany, Dr. Harisingh Gour University (A Central University), \\ Sagar-470003, (M.P.), India
}

Received: July 20, 2018; Accepted: July 24, 2018; Published: July 27, 2018

*Corresponding author: Ashwani Kumar, Assistant Professor, Metagenomics and Secretomics Research Laboratory, Department of Botany, Dr. Harisingh Gour University (A Central University), Sagar-470003, (M.P.), India, Tel: 91-7697432012, E-mail: ashwaniiitd@hotmail.com

\begin{abstract}
Recently production of bio fuel and other platform chemicals from lignocellulosic biomass is gaining constant attention to meet the demand of energy all over the Globe. Utilizing agricultural residues for bio ethanol generation using novel bacterial isolates will provide a solution for energy problem. This study has been conducted with the following objectives; i) to search the novel bacterial isolates that can efficiently degrade the cellulose and ii) their biochemical and molecular characterization by using $16 \mathrm{~S}$ rRNA sequencing. Almost, 15 bacteria's have been isolated from cattle dung out of which 10 isolates showed cellulase activity on CMC (carboxymethyl cellulose) screening media. These bacterial isolates with high cellulase activity were further characterized on the basis of gram staining, morphology and also by various biochemical utilization tests (Citrate, lysine, ornithine, urease, phenylalanine, $\mathrm{H}_{2} \mathrm{~S}$ production, nitrate reduction, glucose, lactose, adonitol, sorbitol, arabinose, and 35 different carbohydrate sources). Results showed that out of three isolates (AKPCD108, AKPCD109 and AKPBD1), the isolate number AKPBD1 showed $58.33 \%$ utilization of biochemical's which is followed by AKPCD108 and AKPCD109, respectively. Among all carbohydrates utilized, AKPBD1 showed $68.57 \%$ utilization and other isolates (AKPCD108 \& AKPCD109) were at par. These three isolates were molecularly identified using $16 \mathrm{~S}$ rDNA sequencing. The obtained sequences were blast and phylogenetic analysis of their sequences showed that AKPCD108 has 99\% similarity with Pseudomonas otitidis strain MCC10330, AKPCD109 has 99\% similarity with Stenotrophomonas koreensis strain TR6-01 (Flavobacterium lutescens) and AKPBD1 has 99\% similar with Serratia marcescens subsp. sakuensis strain KRED. In this study, we conclude that, these isolates are highly promising and have the ability to produce cellulase enzyme and can be used for efficient biological pretreatment of lignocellulosic biomass following production of biofuels and bioproducts.
\end{abstract} Biofuel

Keywords: Cellulolytic bacteria; Lignocelluloses; 16S rDNA; Biomass;

\section{Introduction}

Depletion of fossil fuels and worldwide increases of energy demand and environmental concern has lead in search for an alternative renewable energy resource like lignocellulosic biomass [1,2]. Lignocelluloses are renewable, cost efficient, eco-friendly potential feedstock for the production of bio fuels. However, the bioconversion of this lignocellulosic biomass into sugars is not easy due to the cellulose crystallinity, degree of polymerization, presence of lignin which poses hurdle for enzymatic hydrolysis. Thus, utilizing different pre-treatment methods for bioconversion process increases the overall digestibility of cellulose and hemicelluloses, and therefore removal of lignin from lignocellulosic biomass. However, among the pre-treatment, use of chemical pre-treatment is hazardous for the environment. Therefore, the biological pre-treatment method on the other hand is environmental friendly and gaining popularity now a day because this method is less toxic, requires very low energy input, and much higher sugar yield. The biomass of the plant is mainly composed of cellulose, hemicelluloses and lignin, which constitute an important material to be converted into various type of liquid fuels [3-5].

Present trends to produce cellulosic ethanol has been focused mainly on sorghum, wheat straw, sunflower, maize, sugarcane, and non-edible oil seed plants; however, use of agricultural residues that are not exploited or which could be used more efficiently for ethanol production. The waste material generated from various agricultural fields like stalks, straw, husk, stover, and stems, etc. are highly rich in cellulosic content that had generated great interests to use them as an energy source [6-9]. Among all the component of biomass, cellulose is the principal constituent of the cell wall and mainly composed of units of D-glucose that are linked together to form a linear chain by $ß-1,4$-glycosidic linkages. Cellulose is generally found as micro fibrils that are " 2 $20 \mathrm{~nm}$ " in diameter and "100-40,000 nm" long in the biomass. The enzyme named cellulase has great potential to degrade cellulose and also convert cellulose into simple sugars. Cellulase mainly composed of three major components namely, cellobiohydrolase, endoglucanase or carboxymethylcellulase (CMCase), and betaglucosidases [10]. Microorganism particularly bacteria and fungi produced this enzyme in nature and exploring different natural resources to isolate bacteria is imperative for higher production of cellulolytic enzymes $[11,12]$.

Although, it is validated fact that proper degradation of lignocellulosic substrates requires a complex set of enzymes 
such as laccases, exoglucanases, endoglucanases, peroxidases, fucosidases, xylanases and $\beta$-glucosidases [13]. Variety of microbes that are present in nature like many bacterial and fungal species secretes different types of lignocellulolytic enzymes which help in degradation of lignocellulosic biomass into simple sugars. These sugars can be further converted into bio fuels and other platform chemicals. The present work was conducted to isolate cellulolytic bacteria from cattle dung and to identify them biochemically and molecularly by using $16 \mathrm{~S}$ rRNA gene.

\section{Materials and Methods}

\section{Isolation and selection of bacterial isolates for cellulase activity}

Cattle dung samples were collected in sterile plastic bottles from Sagar, Madhya Pradesh. One gram of dung sample was used to grow bacteria in Nutrient Agar media (Hi Media, India) and incubated at $28^{\circ} \mathrm{C}$ for $48 \mathrm{hrs}$ in incubator and maintained at nutrient broth for further use. Pure culture of bacterial isolates was maintained in separate plate before testing them on selective media. Then $0.1 \mathrm{ml}$ of the bacterial suspension was adjusted to 0.05 cell density by sterile $0.85 \% \mathrm{NaCl}$ solution. Then these bacterial inoculums was transferred to Carboxymethyl Cellulose (CMC) plates for screening CMC activity (Shankar et al., 2011) and incubated at $37^{\circ} \mathrm{C}$ for 2 days. These plates were then flooded with $0.1 \%$ Congo red/Gram's Iodine solution for about $20 \mathrm{~min}$ and then washed by using $1 \mathrm{M} \mathrm{NaCl}$ for $15 \mathrm{~min}$. Formation of the clear halos zones by these bacterial isolates was indicated by their cellulose degrading activity or cellulase activity [14]

\section{Biochemical characterization of cellulase producing bacterial isolates}

A combination of 12 biochemical tests (HiAssortedTM KB002, HIMEDIA, INDIA) and 35 tests for utilization of carbohydrates (HiCarboTM, HIMEDIA, INDIA) were used for biochemical characterization of cellulase producing bacterial isolates by following the instruction provided by the manufacturer. Tests used in this kit are presented in table 1 and table 2. These tests are based on the principle of color change, change in $\mathrm{pH}$, and utilization of substrate by bacterial isolates. The bacterial isolates used for these test were isolated and purified. Only pure cultures were used and kit was opened aseptically. $50 \mu \mathrm{l}$ of the prepared inoculums was added to each well by using surface inoculation method. The kit were also be inoculated by stabbing each individual well with a loopful of inoculums and incubation at $35^{\circ} \mathrm{C}$ temp for $18-24$ hours and changes in color were observed and recorded.

\section{DNA Extraction and molecular identification}

Total genomic DNA of bacterial isolates was extracted by using the Insta Gene TM Matrix Genomic DNA isolation kit. DNA concentration was determined by nano drop. The isolated bacterial DNA was further amplified by using universal forward primer 27F with primer sequence (AGAGTTTGATCMTGGCTCAG) and reverse primer $1492 \mathrm{R}$ with primer sequence
(TACGGTACCTTGTTACGACTT). The PCR mixture contained $1 \mu \mathrm{L}$ of DNA template, and $20 \mu \mathrm{L}$ of PCR reaction mixture. The PCR amplification were performed by using automated thermal cycler (PTC-200, Biorad, Hercules, CA, USA) with the following PCR conditions: an initial denaturation at $94^{\circ} \mathrm{C}$ for about $5 \mathrm{~min}$ followed by 30 cycles of amplification at $94^{\circ} \mathrm{C}$ for $30 \mathrm{~s}$, annealing at $52^{\circ} \mathrm{C}$ for about a min and extension at $72^{\circ} \mathrm{C}$ for $2 \mathrm{~min}$, final elongation at $72^{\circ} \mathrm{C}$ for $10 \mathrm{~min}$. The PCR products were purified using QIAquick PCR Purification Kit (Qiagen, Hilden, Germany) according to the manufacturer's instructions. Selected PCR products were then sequenced using an ABI Big Dye Terminator v3.1 cycle sequencing kit (Applied Biosystems, Grand Island, NY, USA) and these sequences were read on an Applied Biosystems 3130 genetic analyzer (Applied Biosystems). Sequence analysis was performed using Sequence Scanner v1.0 software. Amplified PCR products of $16 \mathrm{~S}$ ribosomal gene were confirmed on $1 \%$ agarose gel, purified using QIAquick PCR purification kit (QIAGEN)

\section{Bioinformatics protocol}

These 16S rDNA sequences were then compared with other sequences available in Gene Bank databases using the NCBI BLAST at http://www.ncbi.n1m.nih.gov/blast/Blast.cgi.Sequences were submitted to NCBI GenBank data base for getting accession numbers. The phylogenetic analysis of sequences with the closely related sequence of NCBI blast results was performed by using the automated NCBI pipeline. A phylogenetic tree for these bacterial sequences were constructed by using iTOL (Interactive tree of life) after establishing relationship among the similar sequences analysis generated from Mega 5.05 software $[15,16]$.

\section{Results and Discussion}

The large number of microorganisms from the diverse environment permits screening for more efficient lignocellulolytic enzymes to help overcome current challenges in bio fuel production [4,17-20]. Previous studies reported that cow/ buffalo dung is rich in cellulase producing bacterial isolates [21]. Therefore, in this study we have tried to isolate good cellulase producing bacteria from the cow dung collected from the Dr. Harisingh Gour University Campus, Sagar, Madhya Pradesh. Almost, 15 bacteria's have been isolated from cattle dung out of which 10 isolates showed cellulase activity on CMC (Carboxymethyl Cellulose) screening media (Figure 1). Cellulase enzyme activities were seen by the appearance of zones around the bacterial colonies on the screening media. Out of ten isolates we selected only three for further characterization; these were named as AKPCD108, AKPCD109 and AKPBD1. These isolates were found to be gram negative after gram staining test. These bacterial isolates with high cellulose activity were tested by gram staining, morphological ground and also by various biochemical utilization tests (Citrate, ornithine, lysine, phenylalanine, urease, $\mathrm{H}_{2} \mathrm{~S}$ production, nitrate reduction, glucose, lactose, adonitol, arabinose, sorbitol and 35 different carbon sources) (Table 1 \& 2). 


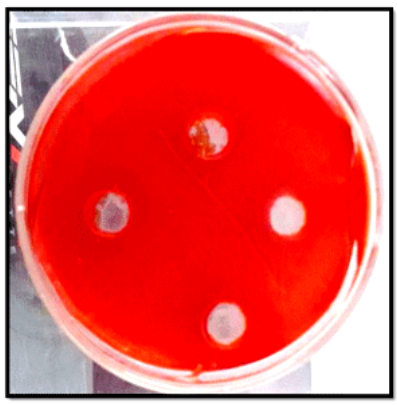

Control

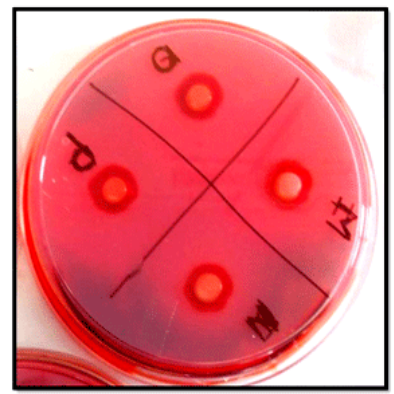

Cellulase activity
Figure 1: Bacterial isolates from buffalo dung showing cellulase activity

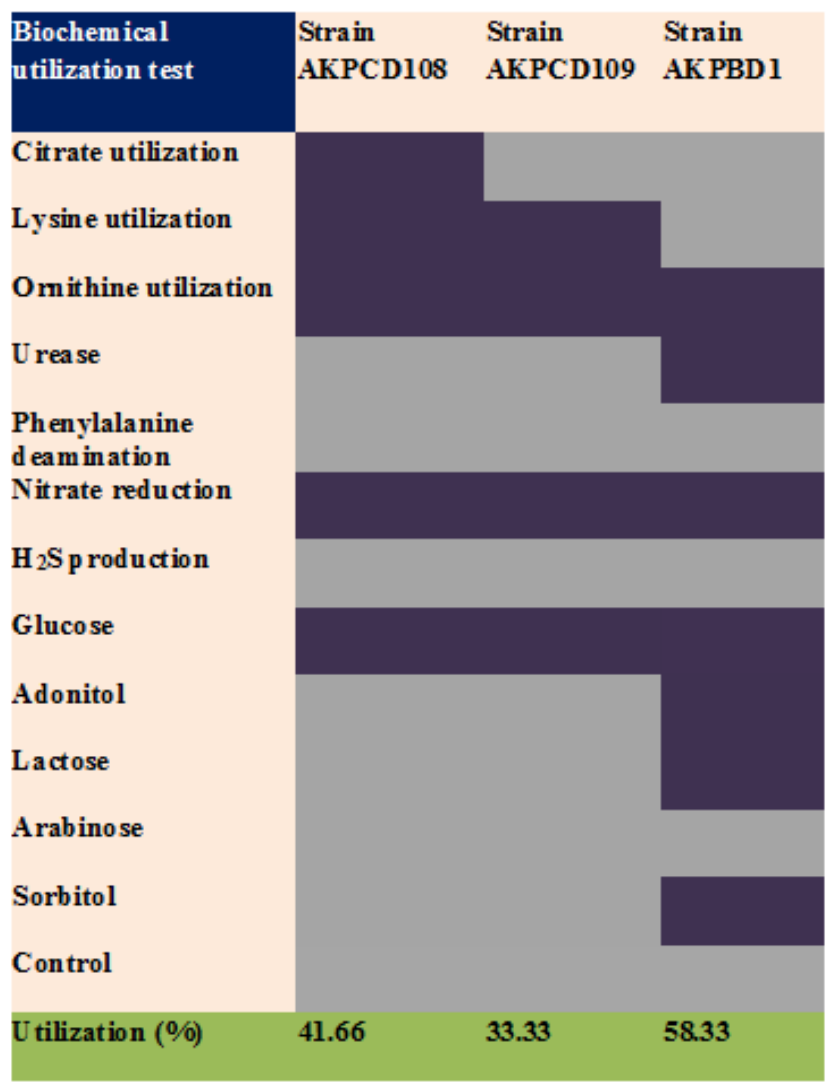

Table 1: Heat map of Biochemical Utilization by selected bacterial isolates from cattle dung

Note: (Dark blue colors indicates positive test for the respective source and grey indicates negative test result.)

Results showed that among these three isolates (AKPCD108, AKPCD109 and AKPBD1), the isolate number AKPBD1 showed $58.33 \%$ utilization of biochemical's (12 different biochemical's and one control) which is followed by AKPCD108 and AKPCD109. Among all carbohydrates (35 different carbon source and one control) utilized, AKPBD1 showed $68.57 \%$ utilization and other isolates (AKPCD108 \& AKPCD109) were at par for the utilization of these carbohydrates (Table 1 and Table 2).

Among the biochemical (ornithine, nitrate and glucose) were utilized by all isolates and phenylalanine and arabinose have not been used by any isolates. On the other hand dextrose, sodium

\begin{tabular}{|c|c|c|}
\hline $\begin{array}{l}\text { Carbohydrates Utilization Test } \\
\text { (35 Carbon Source) }\end{array}$ & $\begin{array}{l}\text { Strain Strain } \\
\text { AKPCD108 AKPCD109 }\end{array}$ & $\begin{array}{l}\text { Strain } \\
\text { AKPBD1 }\end{array}$ \\
\hline \multicolumn{3}{|l|}{ Lactose } \\
\hline \multicolumn{3}{|l|}{ Xylose } \\
\hline \multicolumn{3}{|l|}{ Maltose } \\
\hline \multicolumn{3}{|l|}{ Fructose } \\
\hline \multicolumn{3}{|l|}{ Dextrose } \\
\hline \multicolumn{3}{|l|}{ Galactose } \\
\hline \multicolumn{3}{|l|}{ Raffinose } \\
\hline \multicolumn{3}{|l|}{ Trehalose } \\
\hline \multicolumn{3}{|l|}{ Melibiose } \\
\hline \multicolumn{3}{|l|}{ Sucrose } \\
\hline \multicolumn{3}{|l|}{ L-Arabinose } \\
\hline \multicolumn{3}{|l|}{ Mannose } \\
\hline \multicolumn{3}{|l|}{ Inulin } \\
\hline \multicolumn{3}{|l|}{ Sodium gluconate } \\
\hline \multicolumn{3}{|l|}{ Glycerol } \\
\hline \multicolumn{3}{|l|}{ Salicin } \\
\hline \multicolumn{3}{|l|}{ Glucosamine } \\
\hline \multicolumn{3}{|l|}{ Dulcitol } \\
\hline \multicolumn{3}{|l|}{ In ositol } \\
\hline \multicolumn{3}{|l|}{ Sorbitol } \\
\hline \multicolumn{3}{|l|}{ Mannnitol } \\
\hline \multicolumn{3}{|l|}{ Adonitol } \\
\hline \multicolumn{3}{|l|}{$\alpha$-Methyl-D-Glu conate } \\
\hline \multicolumn{3}{|l|}{ Ribose } \\
\hline \multicolumn{3}{|l|}{ Rhamnose } \\
\hline \multicolumn{3}{|l|}{ Cellobiose } \\
\hline \multicolumn{3}{|l|}{ Melezitose } \\
\hline \multicolumn{3}{|l|}{$\alpha$-Methyl- D-mannoside } \\
\hline \multicolumn{3}{|l|}{ Xylitol } \\
\hline ONPG & & \\
\hline Esculin & & \\
\hline D-Arabinose & & \\
\hline Citrate & & \\
\hline Malonate & & \\
\hline Sorbose & & \\
\hline Control & & \\
\hline Utilization (\%) & 42.86 & 68.57 \\
\hline
\end{tabular}

Table 2: Heat map of Carbohydrate utilization tests of selected bacterial isolates from cattle dung

Note: (Black colors indicates positive test for the respective source and grey indicates negative test result)

gluconate and inositol were used by all the isolates and lactose, melezitose, xylitol have not been used by any isolate. Our results are supported by Khianngam et al. (2014), in which they have screening and identified cellulase producing bacteria from oil palm meal. They obtained 8 isolates belongs to Bacillus, and one to Paenibacillus and Lysinibacillus by using $16 \mathrm{~S}$ rDNA sequencing. The obtained sequences were blast and phylogenetic analysis of their sequences showed that AKPCD108 has 99\% similarity with Pseudomonas otitidis strain MCC10330, AKPCD109 has 99\% similarity with Stenotrophomonas koreensis strain TR6-01 (Flavobacterium lutescens) and AKPBD1 has 99\% similar with Serratia marcescens subsp. sakuensis strain KRED (Table 3). The phylogenetic relationship of these identified cellulase producer are shown in Figures 2a-c. Among the bacterial isolates most common cellulase producer are belong to the following genera; Cellulomonas, Cellvibrio, Clostridium, Paenibacillus, Pseudomonas, Ruminococcus, B. subtilis, B. cereus, B. altitudinis, Paenibacillus, Acetivibrio, Bacillus, Sporocytophaga, Bacteroides, Micrococcus etc $[14,22]$. But the isolates screened in this study for cellulase production were not reported by other workers. 
Table 3: Different bacterial isolates from cattle dung identified using 16SrRNA sequencing

\begin{tabular}{|c|c|c|c|c|c|c|}
\hline S.No. & Isolate number & Bacterial strain & $\begin{array}{c}\text { Gram staining } \\
\text { reaction }\end{array}$ & $\begin{array}{c}\text { NCBI GENE BANK } \\
\text { NO }\end{array}$ & NCBI database match & $\begin{array}{c}\text { Percentage of } \\
\text { identity /Accession }\end{array}$ \\
\hline 1. & AKPCD108 & $\begin{array}{l}\text { Pseudomonas } \\
\text { otitidis }\end{array}$ & Gram negative & KX698105 & $\begin{array}{c}\text { Pseudomonas otitidis } \\
\text { strain MCC10330 }\end{array}$ & 99\%/NR_043289.1 \\
\hline 2. & AKPCD109 & $\begin{array}{c}\text { Flavobacterium } \\
\text { lutescens }\end{array}$ & Gram negative rod & KX698103 & $\begin{array}{c}\text { Stenotrophomonas } \\
\text { koreensis strain TR6- } \\
01\end{array}$ & 99\%/NR_041019.1 \\
\hline 3. & AKPBD1 & $\begin{array}{c}\text { Serratia } \\
\text { marcescens }\end{array}$ & Gram negative rod & KX698107 & $\begin{array}{c}\text { Serratia marcescens } \\
\text { subsp. sakuensis } \\
\text { strain KRED }\end{array}$ & 99\%/NR_036886.1 \\
\hline
\end{tabular}

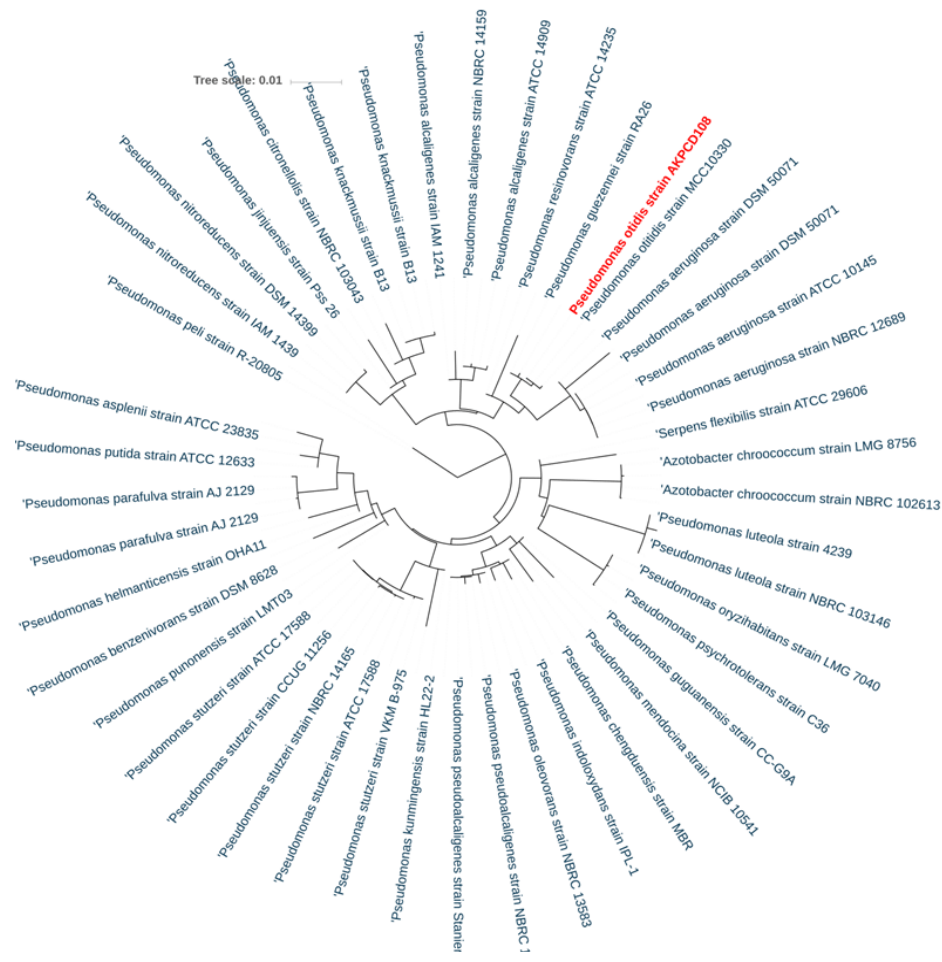

Figure2 (a): AKPCD108 


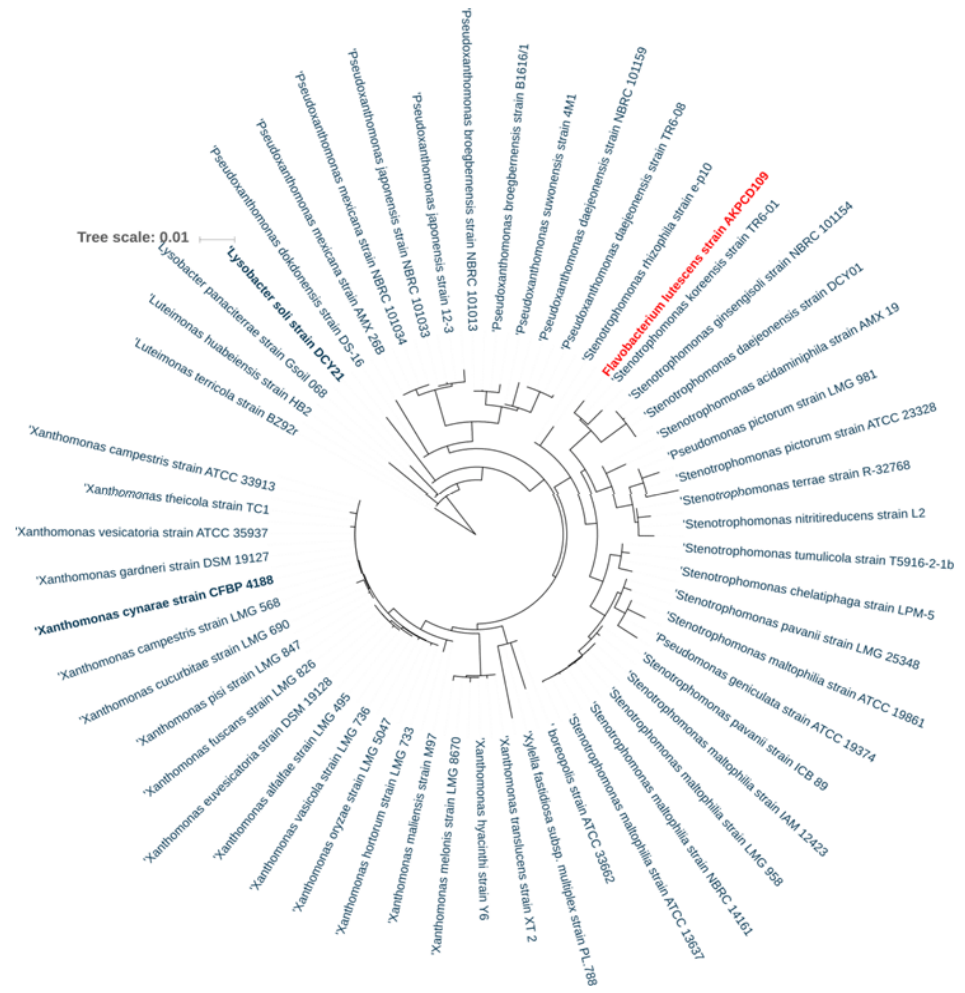

Figure2 (b): AKPCD 109

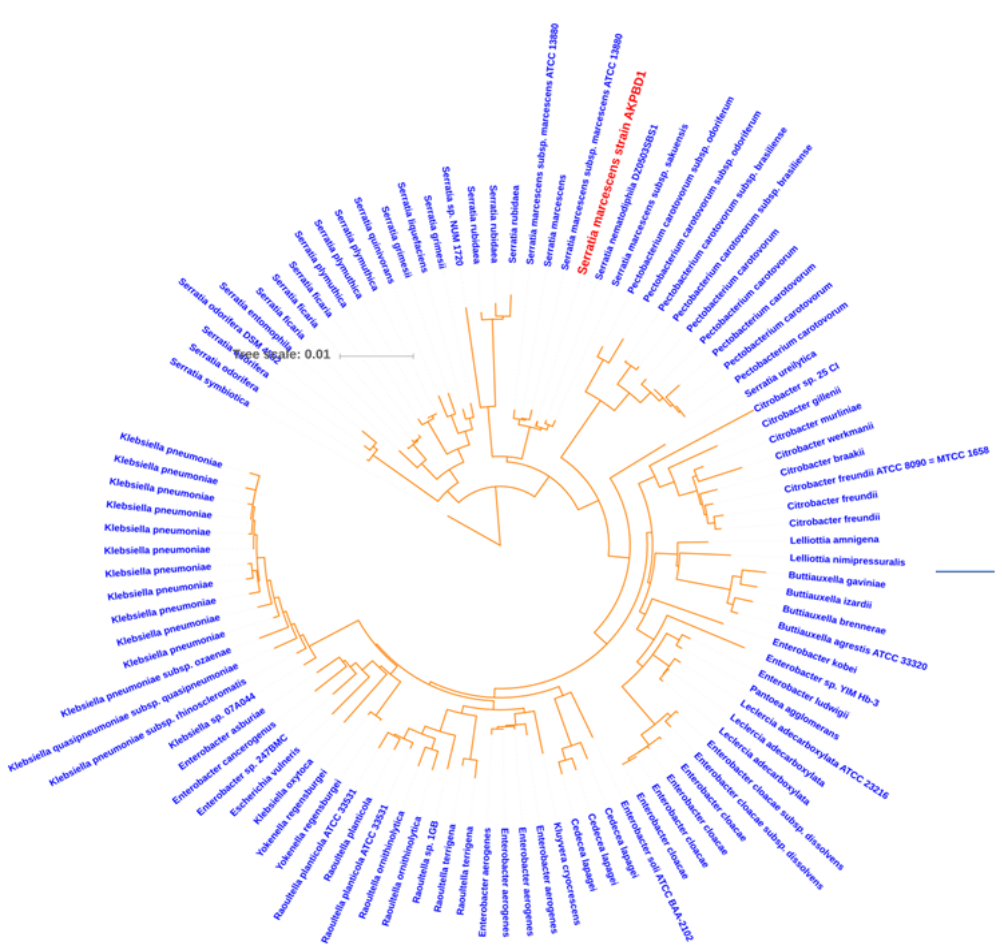

Figure2 (c): AKPBD1

Figure 2: Phylogenetic tree created by iTOL software to present relationship between closely related species 


\section{Conclusion}

In conclusion, 10 cellulase producing bacteria were isolated from cattle dung samples from University Campus, Sagar Madhya Pradesh, India. They were screened for their cellulase activity by Congo red test and they showed hydrolysis capacity on plates. On the basis of their phenotypic characteristics and phylogenetic analyses, three isolates AKPCD108, AKPCD109 and AKPBD1 were closely related to Pseudomonas, Stenotrophomonas and Serratia marcescens, respectively. However, the further research on these isolates would be required utilize their full potential or to maximise the production of cellulase enzymes and degradation of agriculture residues. Finally based on the present research it can be concluded that cattle dung can be a very good source for the isolation of cellulase producing bacteria and their advance biotechnological application, mainly for biomass hydrolysis.

\section{Contributory Statements}

PV has conducted the experiment. AK proposed the experiments, prepared and edited the manuscript.

\section{Acknowledgement}

PV and AK would like to acknowledge the UGC Start-up grant (Awarded to AK) for the financial support. Authors would like to acknowledge Ms. Anamika Dubey (DST Inspire) for valuable suggestions.

\section{References}

1. Sharma HK, Xu C, Qin W. Biological Pretreatment of Lignocellulosic Biomass for Biofuels and Bioproducts:An Overview. Waste and Biomass Valorization. 2017;1-17.

2. Ahmad S, Pathak V V, Kothari R, Kumar A, Babu S, Krishna N. Optimization of nutrient stress using $\mathrm{C}$ pyrenoidosa for lipid and biodiesel production in integration with remediation in dairy industry wastewater using response surface methodology.3 Biotech. 2018.

3. Vyas P, Kumar A, Singh S. Biomass breakdown: A review on pretreatment, instrumentations and methods. Front Biosci. 2018;10:155-174.

4. Raghunandan K, Mchunu S, Kumar A, Kumar KS, Govender A, Permaul K, Singh S, et al. Biodegradation of glycerol using bacterial isolates from soil under aerobic conditions. J Environ Sci Heal Part A Toxic/Hazardous Subst Environ Eng. 2014;49(1):85-92. doi: 10.1080/10934529.2013.824733

5. Tiwari G, Sharma A, Dalela M, Gupta R, Sharma S, Kuhad RC. Microwave assisted alkali pretreatment of fruit peel wastes for enzymatic hydrolysis. Indian J Agric Sci. 2017;87(4):496-499.

6. Tiwari G, Sharma A, Kumar A, Sharma S. Assessment of microwaveassisted alkali pretreatment for the production of sugars from banana fruit peel waste. Biofuels. 2018

7. Gupta A, Kumar A, Sharma S, Vijay VK. Comparative evaluation of raw and detoxified mahua seed cake for biogas production. Applied Energy. 2013;102:1514-1521.
8. Kumar A, Sharma S. Potential non-edible oil resources as biodiesel feedstock: An Indian perspective. Renew Sustain Energy Rev. 2011;15(4):1791-1800.

9. Kothari R, Pandey A, Ahmad S, Kumar A, Pathak V V, Tyagi V V. Microalgal cultivation for value-added products: a critical enviroeconomical assessment. 3 Biotech. 2017;7:243.

10. Bhat MK. Cellulases and related enzymes in biotechnology. Biotechnol Adv. 2000;18(5):355-383.

11. Raghunandan K, Kumar A, Kumar S, Permaul K, Singh S. Production of gellan gum, an exopolysaccharide, from biodiesel-derived waste glycerol by Sphingomonas spp. 3 Biotech. 2018;8(1):71. doi: 10.1007/s13205-018-1096-3

12.Singh JK, Vyas P, Dubey A, Upadhyaya CP, Kothari R, Tyagi VV, Kumar A, et al. Assessment of different pretreatment technologies for efficient bioconversion of lignocellulose to ethanol. FrontBiosciSch. 2018;10:350-371.

13. de Lima Brossi MJ, Jiménez DJ, Cortes-Tolalpa L, van Elsas JD. SoilDerived Microbial Consortia Enriched with Different Plant Biomass Reveal Distinct Players Acting in Lignocellulose Degradation. Microb Ecol. 2016;71(3):616-627. doi: 10.1007/s00248-015-0683-7

14. Khianngam S, Pootaeng-on Y, Techakriengkrai T, Tanasupawat S. Screening and identification of cellulase producing bacteria isolated from oil palm meal. J. Appl. Pharm. Sci. 2014;4(4):90-96.

15. Kimura M. A simple method for estimating evolutionary rates of base substitutions through comparative studies of nucleotide sequences. J Mol Evol. 1980;16(2):111-120.

16. Letunic I, Bork P. Interactive tree of life (iTOL) v3 : an online tool for the display and annotation of phylogenetic and other trees. Nucleic Acid Res. 2016;44(1):242-245. doi: 10.1093/nar/gkw290

17. Lokhande, $\mathrm{S}$ and Pethe AS. Isolation and screening of cellulolytic bacteria from soil and optimization of cellulase production and activity. Int J Life Sci. 2017;5(2):277-282.

18.Gothwal R, Gupta A, Kumar A, Sharma S, Alappat BJ. Feasibility of dairy waste water (DWW) and distillery spent wash (DSW) effluents in increasing the yield potential of Pleurotus flabellatus (PF 1832) and Pleurotus sajor-caju (PS 1610) on bagasse. 3 Biotech. 2012;2(3):249-257.

19. Singh NB, Kumar A, Rai S. Potential production of bioenergy from biomass in an Indian perspective. Renew Sustain Energy Rev. 2014;39:65-78.

20.Kumar A, Kumar K, Kaushik N, Sharma S, Mishra S. Renewable energy in India: Current status and future potentials. Renew Sustain Energy Rev. 2010;14(8):2434-2442.

21. Maki ML, Broere M, Leung KT, Qin W. Characterization of some efficient cellulase producing bacteria isolated from paper mill sludges and organic fertilizers. Int J Biochem Mol Biol. 2011;2(2):146-154.

22.Sethi S, Datta A, Gupta BL, Gupta S, Sethi S, Datta A, et al. Optimization of Cellulase Production from Bacteria Isolated from Soil. Int Sch Res Not. 2013:e985685. 